social obligation. That Gorbachev is at least trying should be apparent from recent events in the Baltic republics, where popular movements apparently aimed at outright secession (not generally regarded as an essential human right, especially in the United States) have been dealt with by compromise, not suppression.

Especially because, on this occasion, daring need not be compromised by military weakness, there is therefore the strongest case for taking Gorbachev's agenda for the future seriously. That his account of the future is unfamiliar to at least two-thirds of those now alive makes it seem strange, and dangerous for that reason. But that sense, that the proffered future is weirdly unfamiliar, is but another way of recognizing historic change. Will it not be cowardly to let it slip?

\section{Tongues shall not wag}

\section{British plans for a law on secrecy are an improve- ment, but are still deficient.}

Most governments have secrets. The British government has more than most, but no effective legislation to protect them. Instead, there is only the Official Secrets Act (1911), whose second (of two) sections prohibits everybody from disclosing or passing-on official information whose disclosure has not been "authorized". The result is that ministers (by definition the embodiments of authority) can selectively release public information to put a partial gloss on their own doings, but that all others, public servants and journalists in particular, do not know where they stand when using unauthorized official information. That part of the act (the other makes espionage a crime) has become unworkable: lawyers cannot easily make a case, and juries are reluctant to convict. That is why the British government is now embarked on amending legislation. A few months ago, it advertised its intentions (see Nature 334, 1; 7 July 1988). Now, it is pushing an amending bill through the British parliament.

These events adequately explain why previous governments have shrunk from the task. The new bill is a step forward in excluding from criminal sanction information about much routine government business. Instead, there will be six categories of protected information, dealing with intelligence, defence and foreign relations; interested parties will now know better where they stand. But the government has still not come to grips with the philosophical difficulty underlying the protection of secrets in a modern democracy, that of telling when the goal of protecting secrets, even those justly classified as such, must be overridden by other considerations, that of public discussion of intelligence activity which is illegal, or of defence procurement that wastes public money, for example.

Indirectly, the government is seeking to turn part of this objection with a second bill whose effect is to put the British intelligence services on a statutory basis, which amounts to acknowledging that they exist. Under these arrangements, the work of the services will be overseen by a committee of the great and the good reporting to the government. The same bill provides for a procedure by which the spooks can both tap people's telephones and - a new departure - burgle people's houses (court orders will be required). The intention is that the existence of the committee should meet the objection that the duty of absolute secrecy now placed on intelligence officers would stifle complaints from those who are ordered to act illegally. Sadly, in British circumstances, nobody can be sure that an internal committee will have that effect.

More generally, the government is resisting the notion that there can be a legitimate public interest in the disclosure of information otherwise classified as secret. While the bill now being debated is an improvement on the version advertised earlier in the year, particularly in its acknowledgement that those publishing secret information that should not have been disclosed to them will be able to plead that the public interest mitigates the harm they have done, that is not the same as a fullthroated acknowledgement that occasions may arise when public servants have a duty of conscience to make official secrets public. What, say, if an official knew that some future government was supplying fissile materials to other governments in contravention of its treaty obligations, or using sanctioned burglary to outwit political opponents? The Nuremberg trials after the Second World War were predicated on the principle that public servants must, in the last resort, put conscience above their instructions from above. That is the principle that should now be written into the new British legislation.

\section{Guns out on butter}

\section{Wealthy manufacturing nations should not also hog the world's trade in agriculture.}

THE collapse last week of the trade talks at Montreal is a bad business from which everybody stands to suffer. What happened is easily described, but less easily understood. Briefly, the members of the General Agreement on Tariffs and Trade (GATT), which include the major economies of the world except the Soviet Union and those of Eastern Europe, have undertaken to negotiate among themselves an extension of the present rules governing international trade in manufactured goods to novel fields, notably agriculture and services (insurance for example). At the same time, they had undertaken among themselves to liberalize trade in the products of developing countries, from tropical products to textiles. The meeting at Montreal was meant to speed a process that has languished for too long since its beginning at a conference in Uruguay two years ago. Instead, the meeting seems merely to have confirmed the chief negotiators in their obduracy.

The central issue, on which the meeting foundered, is that of how agricultural subsidies should in future be regulated in the United States and the European Community, each of which spends roughly $\$ 30,000$ million a year at present. Logically, the extension of GATT rules to agriculture would require that all farmers' subsidies should be abolished. The obvious snag is that agricultural subsidy is a central feature of the Treaty of Rome from which the European Community derives its existence. The original idea was the mistaken notion that, in a community whose wealth stems largely from manufacturing industry, rural communities would indefinitely be impoverished if they were not offered prices for their produce linked with the general increase of prosperity. In the event, of course, agricultural prices have been too attractive, European farmers have most often over-produced - and European consumers have been overcharged for the food they eat. But agricultural protection remains central to the Treaty of Rome.

The United States, generally the cheapest food-producer in the world, has been repeatedly affronted by this state of affairs. European markets have been effectively closed (by tariffs) to low-cost US producers, while bargain sales of European food surpluses to third countries (grain to Egypt, butter to the Soviet Union) have prevented even efficient US farmers from balancing their books. Whence President Reagan's declaration two years ago that the world would be a happier place if agricultural subsidies were totally abolished by the year 2000 .

The immediate cause of trouble last week was US insistence on not budging from its demand that Europe should commit itself to abolish subsidies by 2000 , which would plainly have been impossible without endless prior political negotiation in Europe. If the United States had been a little more subtle, it would have been made plain that Europe is equally inflexible on several issues, not least its unwillingness to see imports replace its own farmers' produce. That is why Europe has a bigger task ahead than the United States, and - if the talks planned for the next four months should fail - - will bear a greater responsibility. $\square$ 